\title{
Infection on the meshes implantation area in the abdominal wall of rats with induced bacterial peritonitis ${ }^{1}$
}

\author{
Infecção no sítio de implantação de telas de polipropileno em parede abdominal \\ de ratos com peritonite bacteriana induzida
}

\author{
Geraldo Alberto Sebben², Sérgio Luiz Rocha ${ }^{3}$, Luiz Carlos Von Bahten ${ }^{4}$, Maria de Lourdes Pessole Biondo-Simões 5 , \\ Fernando Henrique Azevedo Ramos ${ }^{6}$, Marcelo Pilonetto ${ }^{7}$, Luciana Munhoz Zonatto ${ }^{8}$ \\ 1. Research performed in Post-Graduation Program on Surgical Clinic of the Pontifícia Universidade Católica do Paraná (PUCPR). Brazil. \\ 2. Gastrointestinal Surgeon. Assistant Professor of Medical Anatomy at PUCPR. Brazil. \\ 3. Full Professor of Medical Anatomy, Federal University of Paraná (UFPR), Associate Professor of Surgical Techniques and Experimental \\ Surgery at PUCPR. Brazil. \\ 4. Associate Professor of Medical Anatomy, Assistant Professor of Surgery Department at UFPR. Brazil \\ 5. Full Professor of Scientific Methodology at Post-Graduation Program on Surgical Clinic at PUCPR, Associate Professor of Surgical \\ Techniques and Experimental Surgery at UFPR \\ 6. Surgeon at São Vicente Hospital of Curitiba, Paraná. Brazil. \\ 7. Full Professor and Chief of the Microbiology Laboratory at PUCPR. Brazil. \\ 8. Student of Biochemistry Course at PUCPR. Brazil.
}

\begin{abstract}
Purpose: Evaluate incidence of bacterial growth on implanted meshes in the abdominal wall of rats after to induce bacterial peritonitis. Methods: 36 rats were used. They were allocated in two groups: group B, experiment group $(\mathrm{n}=18)$ and group $\mathrm{S}$, control group $(\mathrm{n}=18)$. They were submitted to the implant of polypropylene meshes on the abdominal wall, at the preperitoneal space. Then, in the animals of the experiment group, the induction of peritonitis was made through the inoculation in the peritoneal cavity of standardized solution of Escherichia coli. In the animals of the control group it was made through the inoculation of physiologic solution. The animals of both groups were reallocated in three subgroups of six animals and observed until the reoperations time, for evaluation of the implantation sites, collection of the meshes for cultures, evaluation of the abdominal cavity and peritoneal lavage for cultures. The reoperations occurred in 24,48 and 72 hours. Results: All the animals of the experiment group presented clinical symptoms of peritonitis. The cultures of the meshes taken off from the implantation sites were positive in $83 \%$ of the animals when the moment of the evaluations was of 24 hours, decreasing to $33 \%$ in 48 hours and $17 \%$ in 72 hours. Globally, it was of $44 \%$. In the animals of the control group there was no case of positive culture neither in the meshes, nor in the peritoneal lavages. Conclusions: The experimental model used was effective, producing $100 \%$ of peritonitis. The incidence of bacterial growth on the implanted polypropylene meshes was $83 \%$ in 24 hours, decreasing with the time.
\end{abstract}

Key words: Surgical Mesh. Ventral, Hernia. Infection. Peritonitis. Rats.

\section{RESUMO}

Objetivo: Avaliar a incidência do crescimento bacteriano em telas de polipropileno implantadas na parede abdominal de ratos, após a indução de peritonite bacteriana. Métodos: Utilizaram-se 36 animais alocados em dois grupos: grupo B, experimento $(n=18)$ e grupo $S$, controle $(n=18)$. Os ratos foram submetidos ao implante de telas de polipropileno na parede abdominal, no espaço pré-peritoneal. Em seguida, nos animais do grupo experimento, procedeu-se à indução de peritonite pela inoculação na cavidade peritoneal de solução padronizada de Escherichia coli. Nos animais do grupo controle procedeu-se à inoculação de solução fisiológica. Os animais de ambos os grupos foram realocados em três subgrupos de seis animais e acompanhados até as reoperações para avaliação dos sítios de implantação, coleta das telas para culturas, avaliação da cavidade e lavados peritoneais para culturas. As reoperações ocorreram com 24, 48 e 72 horas. Resultados: Todos os animais do grupo experimento apresentaram quadro de peritonite. As culturas das telas retiradas dos sítios de implantação mostraram-se positivas em $83 \%$ dos animais quando o momento das avaliações foi de 24 horas, diminuindo para 33\% em 48 horas e 17\% em 72 horas, globalmente foi de 44\%. Nos animais do grupo controle não houve nenhum caso de cultura positiva, tanto nas telas quanto nos lavados peritoneais. Conclusões: O modelo experimental utilizado foi efetivo produzindo $100 \%$ de peritonites. A incidência de crescimento bacteriano nas telas de polipropileno implantadas foi de $83 \%$ com 24 horas, decrescendo com o passar do tempo.

Descritores: Telas Cirúrgicas. Hérnia Ventral. Infecção. Peritonite. Ratos. 


\section{Introduction}

The incisional hernias or protrusions of the abdominal wall are frequent complications of the abdominal surgeries made through the laparotomy ${ }^{1}$. Its incidence is estimated in $2 \%$ to $8 \%$ of the operations. The protrusion is a sequel as old as the surgery performance itself and it can occur in up to $12 \%$ of the interventions ${ }^{2}$. There are several techniques for the surgery repair of hernias on the abdominal area and these techniques have been developing along the last years. Basically, they are divided into approaches that make exclusive use of conventional aponeurotics sutures, which may be always tension free. Techniques that make use of auxiliary synthetic prostheses, the meshes, can largely decrease the risk of recurrence, or they can even be the only one option for effective repair of certain abdominal hernias ${ }^{1}$.

The good qualities of the synthetic meshes as well as the surgical techniques that make use of them have been developing a lot in the last years. Nowadays, the use of meshes is being world widely accepted and diffused, especially in difficult and recurrent hernioplasties in large opened techniques or in video laparoscope's ${ }^{3-6}$.

Surgeons frequently face strangulated ventral hernias, which are urgently operated. Total or partial intestine obstruction can be observed and the pain varies according to smaller or larger strangulated intestine strap. A great number of authors have already studied and proved that the presence of bacterial translocation can occur on these cases $^{7-9}$.

The translocation is described as a transportation mechanism of bacteria and its products, more specifically the endotoxines, for sterile organs and tissues, for instance: mesenteric lymph nodes, liver, spleen, lungs, kidney, peritoneal cavity and blood stream ${ }^{10-12}$.

In non-pathological conditions the endogenous bacteria are able to keep stable on the intestinal capillary villi and they contribute with the body defense avoiding the bacteria translocation at the same time the make difficult the clustering of other exogenous bacteria. But, in pathological conditions as the intestinal obstruction caused by many etiologies, like the abdominal hernias with strangulated straps, the bacteria translocation can really occur, as mentioned, and the presence of the bacteria going across the intestinal epithelial barrier can occur within the peritoneal cavity, on the abdominal wall or in the hernial $\operatorname{sac}^{13-15}$.

Furthermore, considering other possible situation of clinical contamination within the peritoneal cavity, like the ones that occurs by intestinal necrosis with perforations, fistulas and bacterial peritonitis. Eligible patients who undergo abdominal surgery with the gastrointestinal tube opened, and are in need of an associated herniorraphy, there is still a doubt about the use or not of surgical prostheses or meshes. The purpose of this study is to clinically induce bacteria peritonitis in rats to evaluate the incidence of the bacteria growth in polypropylene meshes, inoculated in the pre-peritoneal site of the rats' abdominal wall.

\section{Methods}

This study obeyed the Federal Law 6638 and the regulations of the Colégio Brasileiro de Experimentação Animal after being analyzed and approved by the Ethics Committee in Animal Researches of the Pontifícia Universidade Católica do Paraná, during a meeting held on May 27,2004. Operations in rats were made for the polypropylene meshes implantation. Meshes with threads of 0,006 inches of thickness, 60 points per inch, 0,029 inches thick, with pores sized 0,031 x 0,022 inches, Marlex ${ }^{\text {â trade, }}$ sized $1,5 \times 1,0 \mathrm{~cm}$. The implantation was made on the abdominal wall of the pre-peritoneal space, simulating a ventral hernia repair.

36 laboratory animals were used, male Wistar rats, aged 90 days and with a weight variation from $272 \mathrm{~g}$ to $294 \mathrm{~g}$. All animals coming from the laboratory of the Pontifícia Universidade Católica do Paraná. The operations were made in the Surgery Center of the Operation Techniques and Experimental Surgery Subjects at the PUCPR. Animals were feed properly and had free access to water during the experiment. They were studied in cycle day/night of 12 hours in a temperature of $24^{\circ} \mathrm{C}$. They did not receive any antibiotic during the research. The rats were randomly allocated into two groups. It was named group $B$, the experiment group, with 18 rats, in which were implanted the meshes within the pre-peritoneal space followed by the inoculation of patterned bacteria Escherichia coli $0,5 \times 10^{8}$ $\mathrm{UFC} / \mathrm{ml}$, in physiological solution, in peritoneal cavity. It was called group $\mathrm{S}$, the control group, with the 18 rats that underwent through the implantation of meshes in the preperitoneal space followed by the physiological solution inoculation within the peritoneal cavity. The animals of these groups were reallocated in three sub-groups and underwent through re-operation after 24 hours (sub-group B1 e S1), after 48 hours (sub-group B2 e S2) and after 72 hours (sub-group B3 e S3). The rats underwent through operation after anesthetic procedure with ethylic ether, in closed system, abdominal shaving and fixed on the surgical table with sticking plaster. The anti-sepsis was made with local PVPI. An incision with two centimeters was made on the top right quadrant. The abdominal muscle was carefully opened in order to put the polypropylene mesh segment (Figure 1).

Over the polypropylene mesh, the closing of the abdomen was made with monofilament thread of nylon 5.0, as well as the closing of the skin with monofilament thread of nylon 4.0. In the sequence, a puncture was made in left bottom quadrant, for the inoculation of patterned solution of Escherichia coli 0,5 x $10^{8}$ UFC within the peritoneal cavity of the control group rats. Follow-up of the clinical evolution was carefully made. The sub-groups B1 and S1 underwent through re-operation in 24 hours. The sub-groups B2 and S2 in 48 hours and the B3 and S3 in 72 hours, due to the evaluation of the mesh and the site of implantation conditions, and for removing the mesh for cultures. After all, a laparotomy in the bottom left quadrant was made to evaluation of the peritoneal cavity, to make the peritoneal lavage and to collect material for the cultures. 


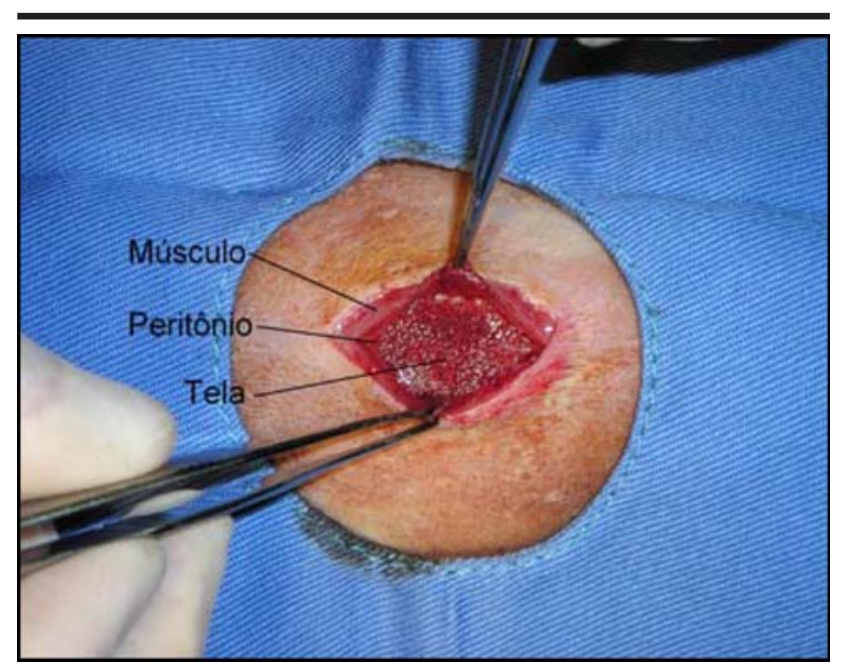

FIGURE 1 - Inputting of the polypropylene mesh in the pre-peritoneal space

Before these operations, the animals were submitted to euthanasia with lethal ethylic ether inhalation dose. The surgical instrumental used in all the primary surgery procedures, as well as in all the re-operations, was sterile and changed after each material collection (meshes and peritoneal lavages) for the cultures, in order not to get any kind of crossed contamination. For the clinical induced peritonitis in the animals, the Escherichia coli bacteria were used, ATCC 25922, group 1184, FAB. February/2004, VAL. February/2006, coming from the Microbiology Laboratory of the PUCPR, where they were cultivated in sterile BHI broth for 24 hours in $36^{\circ} \mathrm{C}$. After this short-term period, turbid broth was observed, what indicates bacteria growth. Part of this broth was taken and diluted to reach a final concentration of $10^{8} \mathrm{UFC} / \mathrm{ml}$, with basis on the patterned scale of Mac Farland. A patterned inoculation of Escherichia coli was reached 0,5 x $10^{8} \mathrm{UFC}$.

After the re-operations, meshes were taken out and peritoneal lavage was made with physiological solution. The collected material was placed in tubes at $36^{\circ} \mathrm{C}$ for 24 hours. The following procedure was sowing the broths in agar bars MacConkey with calibrated strap 1:100, so that isolated colonies were obtained. They were once more incubated at $36^{\circ} \mathrm{C}$ for 24 hours. It was then observed if there was bacteria development and lactose fermentation. Typical colonies and positive lactose were confirmed as bacteria Eschericia coli through conventional biochemical proves ${ }^{16}$.

To follow the groups in each evaluation moment, we tested the worthless hypothesis that the proportional cases with positive culture result were the same in both groups, versus an alternative hypothesis that proportions were different. This analysis was made for the evaluated animals at each moment (24, 48 e 72 hours) and for the total number of animals in each group. For the study of the statistics differences, the exact Fisher's test was used. Values of p d" 0,05 were statistically considered significant.

\section{Results}

All the animals of the experiment group, $n=18$ (Group B and sub-groups B1, B2 e B3), which were inoculated by the bacteria Escherichia coli in patterned solution within the peritoneal cavity, and after the implantation of meshes in the pre-peritoneal spaces, presented clinical symptoms of peritonitis and bacterial infection (anorexia, apathy, pile erection, increasing of the breathing and cardiac frequency) however, with no evolution to death. The meshes and the sites of implantation present inflammatory processes with different intensity and the meshes cultures are positives for the bacteria Gram negative in eight cases (44\%) considering the whole group $B$. The finding outs of the laparotomy during the re-operations were: stench odor, adhesives, located or diffused peritonitis and the presence of one or more peritoneal abscesses (Figue 2).

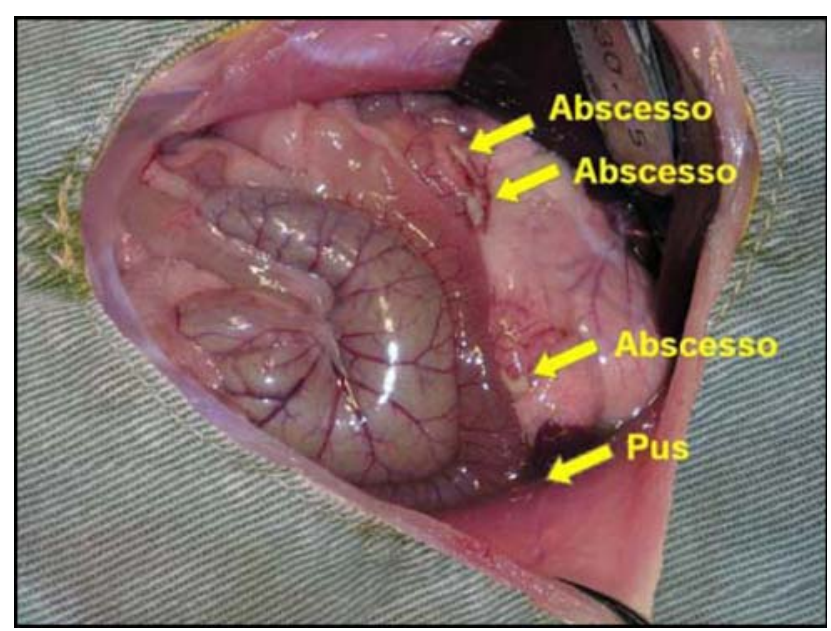

FIGURE 2 - Laparotomy: abscesses and pus in the abdominal cavity

The inspection revealed stench odor and turbid broth through peritoneal lavages and the cultures of the peritoneal lavages for Gram negative bacteria were positive in all the cases and at the whole time. However, when each single group was analyzed, it could be clearly observed that the effect of the time passing by, the percentual of positive cases in mesh cultures were decreasing (Tables 1, 2, 3 e 4). The clinical evolutionary manifestation of the animals coincided with the find outs; they tended to be minor after the first 24 hours. All the animals of the control group, which were inoculated with physiological solution within the peritoneal cavity, did not have any post-operatory clinical alteration after undergoing through meshes implantation. The meshes implantation sites, as well as the meshes themselves, showed very discrete inflammatory reactions in only three cases, but the culture of the meshes in all the cases ere for Gram negative bacteria (Tables 1, 2, 3 and 4).

The laparotomy find outs during the re-interventions, in this group, were normal and the peritoneal lavages for bacteria Gram negative were totally negative in all the cases. 
TABLE 1 - Moment of re-operations: 24 hours

\begin{tabular}{lcc}
\hline Culture (meshes) & Sub-group B1 & Sub-group S1 \\
\hline Positive & $5(83 \%)$ & $0(0 \%)$ \\
Negative & $1(17 \%)$ & $6(100 \%)$ \\
\hline Total & 6 & 6 \\
\hline
\end{tabular}

Value $\mathrm{p}=0,0152$

TABLE 3 - Moment of re-operations: 72 hours

\begin{tabular}{lcc}
\hline Culture (meshes) & Sub-group B3 & Sub-group S3 \\
\hline Positive & $1(17 \%)$ & $0(0 \%)$ \\
Negative & $5(83 \%)$ & $6(100 \%)$ \\
\hline Total & 6 & 6 \\
\hline Value $\mathrm{p}=1$ & &
\end{tabular}

\section{Discussion}

One of the biggest worries of surgeons and researchers along the history of medicine has been the surgery infections matter, specially when it deals with the use of a strange material to organisms, like the meshes used for the abdominal hernias repair. Koonts and Kimberly, mentioned by Debord ${ }^{17}$, affirmed "...we do believe that one of the biggest necessities in surgical interventions is to have a non-metallic and non-absorbable material that may be used for sutures, as well as protheses, and do not cause problems in an infection presence”. Many studies, in sepsis and asepsis conditions were made using several material types like: polyester, nylon, glass fiber, orlon, polyethylene, polyvinyl, scilicone, carbon fiber, and tertafluoroeyhylene. Despite of this, it was Usher ${ }^{18}$ who first introduced the polypropylene mesh, with monofilaments and pores that present as a high quality, permeability to the growth of the granulation and rapid fibroplasy. Jenkins et $\mathrm{al}^{19}$, are also emphasized for their studies of many biomaterials for protesis use, they used polypropylene, polyglactin 910 and polytetrafluoroethylene, which are the most used materials in hernioplasties operations nowadays.

Because of the great development on surgical meshes quality and due to the spreading of surgical techniques that make use of prostheses for abdominal hernias repair by world widely recognized surgeons as Nyhus et al ${ }^{3}$, Lichtenstein et al ${ }^{4}$, Stoppa ${ }^{5}$, Rutkow and Robbins ${ }^{6}$, the use of meshes for disorders on abdominal wall are really diffused nowadays, either on opened surgery interventions or on those made by videolaparoscopy. The advance in the use of meshes in hernioplasties has been important in such a way that a big number of surgeons are now using protesis in a more liberal way, in urgent conditions, incarcerated or strangulated hernias, with intestinal obstruction or even though in hernia operations associated with other surgical interventions potentially contaminated or contaminated, like in the case of the operations within intestinal cavity ${ }^{20-23}$.

The present research focus on the experimental study of the effects caused over the sites of meshes implantation on rats abdominal wall, evaluating the incidence of positive
TABLE 2 - Moment of re-operations: 48 hours

\begin{tabular}{lcc}
\hline Culture (meshes) & Sub-group B2 & Sub-group S2 \\
\hline Positive & $2(33 \%)$ & $0(0 \%)$ \\
Negative & $4(67 \%)$ & $6(100 \%)$ \\
\hline Total & 6 & 6
\end{tabular}

TABLE 4 - Global Result

\begin{tabular}{lcc}
\hline Culture (meshes) & Group B & Group S \\
\hline Positive & $8(44 \%)$ & $0(0 \%)$ \\
Negative & $10(56 \%)$ & $18(100 \%)$ \\
\hline Total & 18 & 18 \\
\hline Value $p=0,0029$ & &
\end{tabular}

cultures in the implanted meshes, when the animals underwent through a clinical induced peritoneal infection. For this study, the polypropylene mesh was used, because of the high adhesive quality, which is very important for the growth of the tissue granulation, fast fibroplasy and mainly because of the easily proliferation of macrophages inside its pores ${ }^{18,24-27}$. Furthermore, in addition to the mentioned qualities, the picked up mesh is the most used among surgeons all over the world. In the present study the peritonitis was induced by inoculating patterned bacteria through the intra-peritoneal solution injection of Escherichia coli with $0,5 \times 10^{8}$ UFC. The model was tested and considered appropriated. There was $100 \%$ of clinical peritonitis, and absolutely no deaths in the timing of 72 hours. The animals, which were part of the present study and, were inoculated with the patterned bacterial solution, presented as time passed by, some clinical alterations, compatible with infection symptoms, like apathy, anorexia and hiperapnea. These clinical alterations were more evident in the first 24 hours, and decreased with the days' evolution. It was also compatible with the find outs during the abdominal cavities exploration and with the meshes cultures that also decreased on positive bacterial results as time passed by. Talking about the cultures of the taken out meshes with clinical bacterial peritonitis, they tended to be globally positive in $44 \%$ of the cases, but the positive sign decreased as time passed by. These facts demonstrate that bacteria are considerable eliminated, from the implanted meshes site by the defensive system of the animal body. This fact was really demonstrated during the present research and possibly occurred due to the macrophages proliferation inside the meshes pores, as described by Aguirre-Córdova and Chávez-Vásquez ${ }^{26}$.

Many authors made experimental studies proving the infiltration of the inflammatory and healing cells with collagen incorporation in surgical meshes ${ }^{24,27-28}$. Another proved tendency is that monothreads meshes, as the polypropylene ones, with smaller surface of contact permit a minor bacterial adhesive and have a better evolution in clinical infections ${ }^{29-30}$. In practice, there are lots of controversies regarding to the use of meshes in operations with potential infection. Some authors are radically against the use of any type of protheses, facing a scarce possibility 
of association with urgency or infectious processes. Stoppa ${ }^{5}$, referring to complicated inguinal and incisional hernias advised against the protheses use in urgent treatments. There is no agreement in using or not the meshes in urgent cases. Some authors assume to have had high numbers of complications with meshes extrusion and enteric fistulas, and for this reason advised against the use of meshes $^{31-32}$. Some others use them even facing clinical infection, intestinal obstruction, or even during big surgeries interventions associated with the opening of the gastrointestinal tract ${ }^{20-23,35}$. They say that in these situations the use of protheses is not absolutely non-indicated because in many cases, the mesh can be the only one option for the closure of the abdominal wall, and help avoiding the closure under tension, that lead to disruption and tissue necroses, factors that are very relevant for recurrences and infections ${ }^{33}$.

Deysine highlighted that, even though the meshes are an area that can be colonized by bacteria, their use contributes for tension-free closure of the wall, decreasing isquemia and death of tissue, significant causes for incidence of infectious contamination ${ }^{34}$. For Astiz et al ${ }^{36}$, infection is not a frequent matter in herniorraphy with meshes in abdominal even tractions repair. When it occurs, is due to important violations of the procedure techniques. Birolini et al ${ }^{22}$, told about the use of polypropylene meshes during operations, associated to other procedures over the upper small intestine. They demonstrated that only three of their 22 patients had infectious matters and they firmly disagree with the authors who advise against the use of meshes in contaminated surgery interventions. In the present study, the final results come up with an incidence of bacterial growth in polypropylene meshes implanted in the abdominal wall of rats that underwent through peritonitis induction, in high level, 83\% when cultures were made after 24 hours. However this incidence was decreasing in the next following hours, reaching 33\% when evaluation was made in 48 hours and 17\% in 72hours, coinciding with the clinical evolution of the animals that were favorable at the ending hours of the experiment. This tendency allows to formulate the hypothesis that, certainly, the polypropylene is fast infiltrated by collagen cells, fibroblasts and macrophages, inside its pores, in the first few subsequent hours of the implantation, and at the end, it eliminates from its surface the bacteria installed by direct contamination or by translocation, through the phagocytic action of macrophages ${ }^{24-27}$. It would explain the reduction of the rates of positive cultures in meshes after the first 24 hours of experiment. A good reason is that when the protheses were implanted during this study, there was no installed infection and the peritoneal space was not opened. Maybe the inputting of the protheses with peritonitis already installed can confirm or reject the affirmations here reported. We do believe that future studies may be realized, referring to the use of meshes in clinical infectious cases, broadening the observation period, making comparisons between the use or not of antibiotics, always looking for the improvement of surgical techniques and the used material. In the other hand, the fear of the use of surgical meshes so intense in a few years behind is possibly dispersing, because the results more and more favorable for their use have been demonstrated all the time.

\section{Conclusions}

1. The model experiment is effective indeed, producing $100 \%$ of peritonitis in all the rats inoculated within the peritoneal cavity with the bacteria Escherichia coli $0,5 \mathrm{x}$ $10^{8} \mathrm{UFC}$.

2. The incidence of bacterial contamination, proved by the cultures, in the polypropylene surgical meshes implanted in the pre-peritoneal site on abdominal wall of rats with concomitant induction of bacterial peritonitis, is $83 \%$ at the moment of the first evaluations and cultures made in 24 hours, decreasing in the other evaluations and cultures made in 48 and 72 hours.

\section{References}

1. Chevrel JP, Flament JB. Traitment des éventrations de la paroi abdominale. Paris: Editions Techniques; 1995.

2. LafuenteAD. Eventraciones. Resúmenes del Curso Anual de Cirurgía da Associación Argentina de Cirurgía; 2002.

3. Nyhus LM, Pollak R, Bombeck CT, Donahue PE. The preperitoneal approach and prosthetic butress repair for recurrent hernia. Ann Surg. 1988; 208(6): 733-7.

4. Lichtenstein IL, Shulman AG, Amid PK, Montllor MM. The tension free hernioplasty. Am J Surg. 1989; 157(2): 188-93.

5. Stoppa RE. The treatment of complicated groin and incisional hernias.World J Surg. 1989;13(5):545-54.

6. Rutkow IM, Robbins AW. Groin hernia: current surgical therapy. Available from URL: http://www.perfixplug.com/groin.htm.

7. Zeni Neto C, Campos ACL, Coelho JCU. Translocação bacteriana em ratos com oclusão intestinal: efeito da isquemia e local da oclusão. Rev Col Bras Cir. 1996; 24:111-6.

8. Akcay MN, Capan MY, Gundogdu C, Polat M, Oren D. Bacterial translocation in experimental intestinal obstruction. J Int Med Res. 1996; 24(1): 17-26.

9. Samel S, Keesse M, Kleczka M, Lanig S, Gretz N, Hafner M, Sturm J, Post S. Microscopy of bacterial translocation during small bowel obstruction and ischemia in vivo: a new animal model. BMC Surg. 2002; 2(1):6.

10. Berg RD, Garlington AW. Translocation of certain indigenous bacteria from the gastrointestinal tract to the mesenteric lymph nodes and other organs in a gnotobiotic mouse model. Infec Immun. 1979; 23(2):403-11.

11. Deitch EA, Bridges WM, Ma JW, Ma L, Berg RD, Specian RD. Obstructed intestine as a reservoir for systemic infection. Am J Surg. 1990; 159(4): 394-401.

12. Rocha SL, Röhrig CE, Santos EAA, Zanelatto-Gonçalves PC, Longhi P, Santos JP. Recuperação em órgãos e tecidos de Escherichia coli ATCC 25922, inoculada no íleo terminal de ratos com obstrução biliar prolongada. Acta Cir Bras. 2001; 16(Supl. 2):33-8.

13. Deitch EA. Simple intestinal obstruction causes bacterial translocation in man. Arch Surg. 1989; 124(6):699-701.

14. De Gaudio AR, Padelletti MB, Leoni M, Tani R, Bartoloni $\mathrm{SO}$, Calzolari A. Induction of bacterial translocation in 
rats with minimal dose of endotoxin. Minerva Anestesiol. 1993; 59(9): 419-25.

15. Antequera R, Bretana A, Cirac A, Brito A, Romera MA, Zapata R. Disruption of the intestinal barrier and bacterial translocation an experimental model of intestinal obstrution. Acta Cient Venez. 2000; 51(1):18-26.

16. Pilonetto M, Pilonetto DV. Manual de procedimentos laboratoriais em microbiologia. Curitiba: Microscience; 1998.

17. Debord JR. The historical development of prosthetics in hernia surgery. Surg Clin North Am. 1998; 78(6): 973-1006.

18. Usher FC, Ochsner J, Tuttle LLD. Use of Marlex mesh in the repair of incisional hernias. Am Surg. 1958; 24:969-72.

19. Jenkins SD, Klamer TW, Parteka JJ, Condon RE. A comparison of prosthetic materials used to repair abdominal wall defects. Surgery. 1983: 94(2): 392-8.

20. Vix J, Meyer C, Rohr S. The treatment of incisional and abdominal hernia with a prostesis in potentially infected tissues: a series of 47 cases. Hernia. 1997 1(4): 157-61.

21. Rohr S, Vix J, Kanor M, Meyer C. Treatment of a massive incisional abdominal wall hernia requiring subtotal colectomy using a dual facing mesh. Hernia. 2000; (Supl.1) 4:22-4.

22. Birolini C, Utiyama EM, Rodrigues AJ, Birolini D. Elective colonic operation and prosthetic repair of incisional hernia: Does contamination contraindicate abdominal wall prosthesis use? J Am Coll Surg. 2000; 191(4):366-72.

23. Kelly ME, Behrman SW. The safety and efficacy of prosthetic hernia repair in clean-contaminated and contaminated wounds. Am Surg. 2002; 68(6): 524-8.

24. Spelzini RI, Brahin FA, Corvalán GM, Rosa MS. Aspectos experimentales del proceso de integración de materiales protésicos implantados en la pared abdominal. Rev Med Tucuman. 1999; 5(4): 191-202.

25. Greca FH, Biondo-Simões MLP, Ioshii SO, El Tawil LI, Stalhschmidt FL, Baggio MR. Correção de defeito criado na parede abdominal de cães utilizando-se rolhas de telas de polipropileno com porosidades distintas: estudo histopatológico. Acta Cir Bras. 2001; 16(Supl. 2): 81-6.

26. Aguirre-Córdova JF, Chávez-Vásquez G. Utilidad del uso de antibióticos en la plastía inguinal con malla reciclada: estudio comparativo. Cir Cir. 2001; 69:173-6.
27. Quintana LFC, Czeczko NG, Cuenca RM, Malafaia O, Nassif PAN, Campos ACL. Avaliação da biocompatibilidade das telas de polipropileno, poliglactina 910 e poliéster no reparo de defeitos da parede abdominal ventral. Estudo experimental. Arq Bras Cir Dig. 2002; 15(4):148-52.

28. Aydos RD, Silva IS, Goldenberg S, Goldenberg A, Simões MJ, Takita LC. Estudo comparativo do efeito das telas de politetrafluoretileno expandido e de polipropileno, colocadas por laparoscopia em hérnias ventrais produzidas em coelhos. Acta Cir Bras. 1999; 14(2):59-64.

29. Klinge U, Junge K, Spellerberg B, Piroth C, Klosterhalfen $\mathrm{B}$, Schumpelick V. Do multifilament alloplastic meshes increase the infection rate? Analysis of the polymeric surface, the bacteria adherence, and the in vivo consequences in a rat model. J Biomed Mater Res. 2002; 63(6): 765-71.

30. Khripun AI, Titkova SM, Makhuova GB, Klyuchikov VY, Ettinger AP, Anurov MV. Use of polytetrafluorethylene films for closing of abdominal cavity under conditions of experimental peritonitis. Bull Exp Biol Med. 2003; 136(4): 420-2.

31. Temudom T, Siadati M, Sarr MG. Repair of complex giant or recurrent ventral hernias by using tension-free intraparietal prosthetic mesh (Stoppa technique): Lessons learned from our initial experience (fifty patients). Surgery. 1996; 120(4): 738-43.

32. Jones JW, Jurkovich GJ. Polypropylene mesh closure of infected abdominal wounds. Am Surg. 1989; 55(1):73-6.

33. Wouters DB, Krom RA, Slooff MJ, Kootstra G, Kuijjer PJ. The use of Marlex mesh in patients with generalized peritonitis and multiple organ system failure. Surg Gynecol Obstet. 1983; 156(5):609-14.

34. Deysine M. Pathophysiology, prevention, and management of prosthetic infections in hernia surgery. Surg Clin North Am. 1998; 78(6): 1105-15.

35. Bauer JJ, Harris MT, Kreel I, Gelernt IM. Twelve-year experience with expanded polytetrafluorethylene in the repair of abdominal wall defects. Mt Sinai J Med. 1999; 66(1):20-5.

36. Astiz JM, Chau O, Beraudo M, Bergé S, Dunogent J. Malla infectada. Rev Argent Cir. 1999; 76(5): 172-6.

\section{Correspondence:}

Geraldo Alberto Sebben

Av. Vicente Machado, 320/ 301

80420-010 Curitiba-PR Brazil

Phone:(55 41)3223-4696

geraldo.sebben@pucpr.br
Conflict of interest: none Financial source: none

Received: January 10, 2006

Review: February 14, 2006

Accepted: March 15, 2006

\section{How to cite this article:}

Sebben GA, Rocha SL, Von Bahten LC, Biondo-Simões MLP, Ramos FHA, Pilonetto M, Zonatto LM. Infection on the meshes implantation area in the abdominal wall of rats with induced bacterial peritonitis. Acta Cir Bras. [serial on the Internet] 2006 May-June;21(3). Available from URL: http://www.scielo.br/acb 